\title{
Strategies to improve the immunosuppressive properties of human mesenchymal stem cells
}

\author{
Myoung Woo Lee ${ }^{1 \dagger}$, Somi Ryu ${ }^{1 \dagger}$, Dae Seong Kim ${ }^{1}$, Ki Woong Sung ${ }^{1}$, Hong Hoe Koo ${ }^{1,2^{*}}$ and Keon Hee Yoo ${ }^{1,3^{*}}$
}

\begin{abstract}
Mesenchymal stem cells (MSCs) are of particular interest for the treatment of immune-related diseases because of their immunosuppressive capacities. However, few clinical trials of MSCs have yielded satisfactory results. A number of clinical trials using MSCs are currently in progress worldwide. Unfortunately, protocols and methods, including optimized culture conditions for the harvest of MSCs, have not been standardized. In this regard, complications in the ex vivo expansion of MSCs and MSC heterogeneity have been implicated in the failure of clinical trials. In this review, potential strategies to obtain MSCs with improved immunosuppressive properties and the potential roles of specific immunomodulatory genes, which are differentially upregulated in certain culture conditions, will be discussed.
\end{abstract}

\section{Introduction}

Human mesenchymal stem cells (MSCs) can be isolated from a wide variety of tissues [1] and are promising candidates for cell-based transplantation and regenerative medicine therapies. Some of the unique features of MSCs that make them attractive targets for therapeutic applications are their tendency to preferentially home to damaged tissues, their unique immunosuppressive properties [2], their capacity for self-renewal, and their multilineage differentiation potential [3]. To date, more than 500 clinical trials involving the infusion or transplantation of MSCs have been registered at ClinicalTrials.gov, and about $20 \%$ of them depend on the immunosuppressive properties of MSCs. Although the immunosuppressive properties of MSCs have been confirmed and most

\footnotetext{
* Correspondence: hhkoo@skku.edu; hema2170@skku.edu

${ }^{\dagger}$ Equal contributors

'Department of Pediatrics, Samsung Medical Center, Sungkyunkwan University School of Medicine, 50 Irwon-Dong, Gangnam-Gu, Seoul 135-710, Korea

Full list of author information is available at the end of the article
}

phase I clinical trials have not shown any biosafety issues, only modest outcomes have been obtained in further trial phases [4-6].

MSCs exhibit heterogeneity not only among donors but also according to the tissue from which they are isolated, such as adipose tissue and bone marrow (BM) [7-9]. Moreover, MSCs isolated from the same tissue of the same donor still tend to exhibit phenotypic and functional variability because of a lack of standardization in preparative protocols and culture methods $[8,10-12]$. Therefore, it may be possible to enhance or suppress a certain function of MSCs by controlling their culture conditions. In this review, potential strategies to obtain MSCs with improved immunosuppressive properties and the potential roles of specific immunomodulatory genes, which are differentially upregulated in certain culture conditions, will be discussed.

\section{Mesenchymal stem cells}

MSCs were first characterized by Friedenstein and colleagues, who identified an adherent, fibroblast-like cell population in adult BM $[13,14]$. The International Society for Cellular Therapy (ISCT) provided three minimal criteria to define human MSCs with regard to their culture characteristics, biomarkers, and developmental potential [15]. First, MSCs must be plastic-adherent when maintained in standard culture conditions. Second, MSCs must express CD105 (SH2), CD73 (SH3/4), and CD90 and must not express CD45, CD34, CD14 CD11b, CD79 $\alpha$, CD19, or HLA-DR. Third, MSCs must differentiate into osteoblasts, adipocytes, and chondroblasts in vitro. These minimal criteria proposed by the ISCT to define human MSCs have been accepted and widely used by many investigators to characterize cells [15]. However, MSCs from different sources and donors and cultured under different conditions do not always behave in the same way in cell therapies, even though they meet the ISCT criteria [8, 16-20]. One possible reason for this discrepancy is that MSCs have many features (such as multipotency; variability of proliferation and migration potential; secretion of various 
cytokines, chemokines, and growth factors; and immunomodulatory functions) which are critical to exert their therapeutic effects; however, the ISCT criteria do not reflect these functional aspects of MSCs [8]. In fact, MSCs have the capacity to differentiate into multiple tissues, including bone, cartilage [21, 22], tendon [23], muscle [24], fat [25], and BM stromal connective tissue, the latter of which supports hematopoietic cell differentiation [26, 27]. In addition, MSCs have immunosuppressive properties and reduce inflammation, suppressing lymphocyte alloreactivity in vitro in mixed lymphocyte reaction assays $[28,29]$. Intravenous administration of MSCs improves the outcome of neural [30] and lung [31] injury in experimental animal models primarily through paracrine effects and a shift from the production of pro-inflammatory to anti-inflammatory cytokines at the site of injury. MSCs exposed to interferon (IFN) $-\gamma$ are activated and suppress graft-versus-host disease (GVHD) in vivo [2]. Thus, the immunosuppressive properties of MSCs may be able to repair tissue damage caused by the immune system in autoimmune-induced inflammatory bowel diseases such as Crohn's disease [32] and ulcerative colitis [33], treat GVHD of the gut, liver, and skin after allogeneic hematopoietic stem cell (HSC) transplantation [34-36], and prevent the rejection of organ transplants [37, 38]. However, the detailed mechanisms underlying the therapeutic effects of MSCs, a heterogeneous population of ex vivo expanded cells [39-41], have not been fully elucidated.

\section{Heterogeneity of mesenchymal stem cells}

MSCs vary tremendously in terms of phenotypic and functional characteristics such as their proliferation capacity, expression of several cell surface markers, and secretion of cytokines [7-10]. Interestingly, although MSCs have been continuously adapted in many laboratories, their heterogeneity is considered to be due mainly to the use of non-standardized culture protocols, including the starting material, culture media, levels of sera/cytokines/oxygen, number of passages, and cell density [7, 42, 43]. In this regard, Ho and colleagues [43] classified MSC heterogeneity as follows: (1) cellular heterogeneity of the initial population, (2) varied expansion capacity of specific subsets of cells and of the final population, and (3) long-term biological function of MSCs. In particular, ex vivo expansion of MSCs is used to develop and maintain MSCs for cell therapy, and the methods used to expand and characterize MSCs are critical for their preparation. Moreover, MSCs express a wide variety of cytokines, chemokines, and growth factors that are important for cell migration, homing, and immunomodulation, following reconstitution of damaged tissues [44-48]. Based on their functional effects, differences in the secretion of these molecules by MSCs may be critical for the outcomes of cell therapies. In this regard, it is important to identify the best subpopulation of cells, to determine how the cells are expanded and characterized ex vivo, and to determine when the cells should be used clinically.

Numerous attempts have been made to develop more specific procedures for the isolation and preparation of appropriate subsets of MSCs from a heterogeneous cell population [7, 11, 43]. The protocol most commonly used in preclinical and clinical studies to isolate MSCs from various tissues is centrifugation over a density gradient followed by ex vivo expansion, which removes hematopoietic cell contamination. With this method, cell recovery from each tissue is variable among operators, and technical expertise is required to consistently obtain MSCs with a high efficiency. In addition, numerous putative human MSC surface markers (i.e., CD49a [49], CD73 [3], CD105 [50], CD106 [51], CD271 [52], MSC antigen-1 [53], Stro-1 [54], and stage-specific embryonic antigen-4 [55]) have been identified thus far. These markers are used alone or in combination to enrich homogeneous MSCs and to avoid cellular contamination. Unfortunately, many of these markers are widely expressed in stromal cells and lack specificity, contributing to the significant heterogeneity among MSCs derived in a single isolation [56].

MSC culture variables include medium formulation, culture surface substrate, cell seeding density, physiochemical environment, and subculture protocols. In particular, the development of well-formulated culture media for the isolation and expansion of MSCs is imperative; however, this is as an extremely difficult process because of the high complexity of media formulations. In this regard, the disclosed medium formulations for MSCs (e.g., those reported in [57-60]) are best positioned to be further developed by the many investigators interested in the therapeutic applications of MSCs. Unlike some cell types, MSCs can survive in hypoxic environments for several days by upregulating survival pathways $[61,62]$ and increasing cellular metabolism [63]. Cell numbers are also increased when cells proliferate under low oxygen tension $[64,65]$. Differentiation into different mesenchymal lineages can be enhanced by culture under some hypoxic conditions [66, 67]; however, the effects seem to depend on various variables such as the exact oxygen tension, time in culture, and use of hypoxic preculture. Moreover, hypoxic conditions enhance the paracrine role of MSCs by altering cytokine and growth factor release [68-70] and play an import role in mobilizing MSCs and recruiting them to sites of injury [69, 71, 72]. Thus, hypoxic preconditioning of MSCs prior to implantation and associated hypoxic conditioned medium can improve cell survival in vivo, which has significant effects on the long-term effectiveness of MSC therapy. However, 
protocols to prepare and characterize MSCs have not been standardized. If the heterogeneity of MSCs cannot be minimized, it might take a long time to produce satisfactory clinical results.

In recent years, preparing cell therapy products using MSCs often required complex procedures, such as multiple cell-selection steps, ex vivo expansion, cell activation (e.g., priming or licensing), encapsulation, and genetic modifications $[73,74]$. These complex procedures reflect the increasing sophistication of cell therapies and their production methods but have also occurred in response to the potential risks and increasingly rigorous regulatory requirements for these novel cell therapies. In fact, among the methods described above, ex vivo expansion and cell activation may have only minimal regulatory issues in terms of their clinical application because ex vivo expansion is a general method used in cell culture and cell activation is a simple method in which cells are merely primed with cytokines such as IFN- $\gamma$, which are commercially available and approved by the US Food and Drug Administration for the treatment of several diseases [72, $75,76]$. However, there are many concerns regarding the use of engineered or modified cell therapy products for clinical applications, and appropriate solutions need to be developed in the near future.

\section{Modulating cell confluency to overcome mesenchymal stem cell heterogeneity}

As previously mentioned, despite the well-known advantageous biological properties of MSCs, they have not been successfully adapted in clinical trials, because of the lack of standardized protocols, and this has resulted in their notorious heterogeneity. Many studies have examined the expansion capability and phenotypic properties of MSCs; however, the underlying mechanisms and the types of genes involved have been neglected. Among the various growth conditions, cell confluency is suggested to be a primary factor that can affect the characteristics of highly heterogeneous MSCs [77, 78]. MSCs have a better proliferation capacity when they are grown at a low confluency because this provides the space for cells to proliferate and means that nutrients and oxygen are shared by fewer cells [7, 42, 43]. A low initial plating density is considered to be beneficial for ex vivo MSC expansion [7-10]; however, most studies have investigated the effect of the initial plating density on the capability of MSCs to differentiate or expand in vitro, not on their biological functions in vivo [7, 11, 43]. By contrast, we reported that genes linked to immunity, defense, cell communication, signal transduction, and cell motility are more highly upregulated in MSCs harvested at a high confluency than in MSCs harvested at a low confluency $[79,80]$. These reports also indicate that the immunosuppressive properties of MSCs are enhanced via complex pathways involving these upregulated genes. Thus, ex vivo expansion of MSCs and harvesting of MSCs at an adequate density could be a promising strategy to prepare MSCs for use in regenerative medicine.

\section{Cell proliferation-related genes are upregulated mainly in} mesenchymal stem cells at a low density

Changes in the expression levels of cell proliferationrelated genes during in vitro MSC culture are important for the capability of these cells to further proliferate and differentiate [78, 81, 82]. Previous studies suggest that a low initial plating density results in faster MSC expansion, leading to higher MSC yields [7, 11, 43]. Growth at higher densities is constrained by density-dependent growth inhibition; therefore, cells plated at a lower density have a higher doubling number per passage. Our gene expression profile data showed that 29 genes regulating proliferation, differentiation, and cell cycling activities were upregulated in MSCs harvested at a low confluency $(50 \%)$ but that only four of these genes were upregulated in MSCs harvested at a high confluency (>90 \%) [79]. At a lower plating density, MSCs were dispersed evenly over the plate and rapidly filled the available space over time. As cells became confluent, their proliferation slowed because of cell-to-cell contact and this was reflected in the reduced expression of proliferation-related genes. Therefore, the improved proliferation rate of MSCs at a low confluency is due not only to the higher availability of space and conditions that increase the number of cells but also to the interactions of genes. However, the influence of gene expression levels on the proliferation potential of MSCs must be investigated further.

\section{Genes related to the functional characteristics of} mesenchymal stem cells, including immunomodulation, are more highly expressed in high-density cultures

Our microarray analysis showed that a number of genes (276 of 24,526 genes) that control biological functions, including immunosuppression-such as prostaglandin $\mathrm{D}_{2}$ synthase (PTGDS), prostaglandin E synthase (PTGES), chemokine (C-X-C motif) receptor type 7 (CXCR7), vascular cell adhesion molecule 1 (VCAM1), and naturalkiller group 2 member D (NKG2D) ligand 1 (ULBP1)were highly upregulated in MSCs at a high confluency (Table 1 and Fig. 1) [79, 80]. These genes reportedly directly or indirectly (or both) affect the immunomodulatory activities of MSCs. Specifically, PTGDS and PTGES synthesize prostaglandin (PG) $E_{2}$, which can stimulate or inhibit the activities of antigen-presenting cells (APCs), inhibit the proliferation of immature B cells and $\mathrm{T}$ cells, and regulate intracellular calcium release and p59(fyn) protein tyrosine kinase activity [83-85]. Although it remains controversial whether other types of 
Table 1 Gene Ontology analysis based on immunomodulatory function-associated genes upregulated in high-density MSC cultures (>90 \%)

\begin{tabular}{|c|c|c|c|c|}
\hline Gene Ontology Category_Biological Process & Total number of genes & Number of upregulated genes & Enrichment & $P$ value \\
\hline GO:0005576_extracellular region & 21,529 & 91 & 17.89 & $<0.001$ \\
\hline GO:0022610_biological adhesion & 6813 & 37 & 8.31 & $<0.001$ \\
\hline GO:0002253_activation of immune response & 1360 & 6 & 3.87 & 0.016 \\
\hline GO:0016477_cell migration & 5281 & 14 & 3.53 & $<0.001$ \\
\hline GO:0042981_regulation of apoptosis & 7116 & 26 & 2.1 & $<0.001$ \\
\hline GO:0006955_immune response & 6130 & 23 & 1.81 & 0.0012 \\
\hline GO:0050920_regulation of chemotaxis & 598 & 3 & 1.79 & 0.084 \\
\hline GO:0048771_tissue remodeling & 632 & 5 & 1.67 & 0.001 \\
\hline GO:0001558_regulation of cell growth & 1805 & 8 & 1.32 & 0.033 \\
\hline GO:0042611_MHC protein complex & 759 & 4 & 1.05 & 0.063 \\
\hline
\end{tabular}

Microarray analysis was performed to compare the gene expression profiles of MSCs that were seeded at a density of 200 and 5000 cells/cm ${ }^{2}$, which were around $50 \%$ and $90 \%$ confluent on day 7, respectively. Upregulated genes in MSC cultures seeded at a density of 5000 cells/cm ${ }^{2}$ were sorted on the basis of gene expression profiles (fold change $>2$ and $P$ value $<0.05$ ) and classified according to their related biological processes based on Gene Ontology terms by using DAVID Bioinformatics Resources 6.7

MSC mesenchymal stem cell, DAVID Database for Annotation, Visualization and Integrated Discovery

PG function as pro- or anti-immunomodulatory molecules, PTGES is remarkable in terms of its immunosuppressive activities [84, 85]. The ability of MSCs to migrate, which is determined mainly by a panel of signals including chemokines, is closely related to the functions of MSCs in immune regulation and tissue repair [86]. CXCR7, which mainly activates mitogen-activated protein kinases and induces signaling following ligand binding, can regulate the immune system and inflammation via $G$ protein-coupled receptors [87, 88]. Recently, many studies demonstrated that CXCR7, not chemokine (C-X-C motif) receptor 4 (CXCR4), mediates stromal cell-derived factor 1 (also known as CXCL12)-induced migration of various cells, including MSCs, and BM engraftment of cultured HSCs [89-92]. In addition, several studies have reported that MSCs can selectively migrate to specific injury sites after systemic infusion. This migration is mediated by very late antigen 4 (VLA4) and VCAM1, which allow MSCs to adhere to vascular endothelial cells and subsequently cross endothelial barriers $[93,94]$. A certain type of APC assists the interaction of VCAM1 with VLA4 such that MSCs can migrate to inflammation sites and regulate $\mathrm{T}$ cellmediated inflammation and pathology in non-lymphoid tissues [95-97]. On the other hand, ULBP1 is a ligand for NKG2D receptor, and the interaction of ULBP1 and NKG2D is reportedly essential for the delivery of activating signals to natural killer (NK) cells or the regulation of T-cell receptor-mediated activation of $\mathrm{T}$ cells or both [98-101]. We clearly showed the inhibitory roles of ULBP1 in the regulation of T-cell proliferation

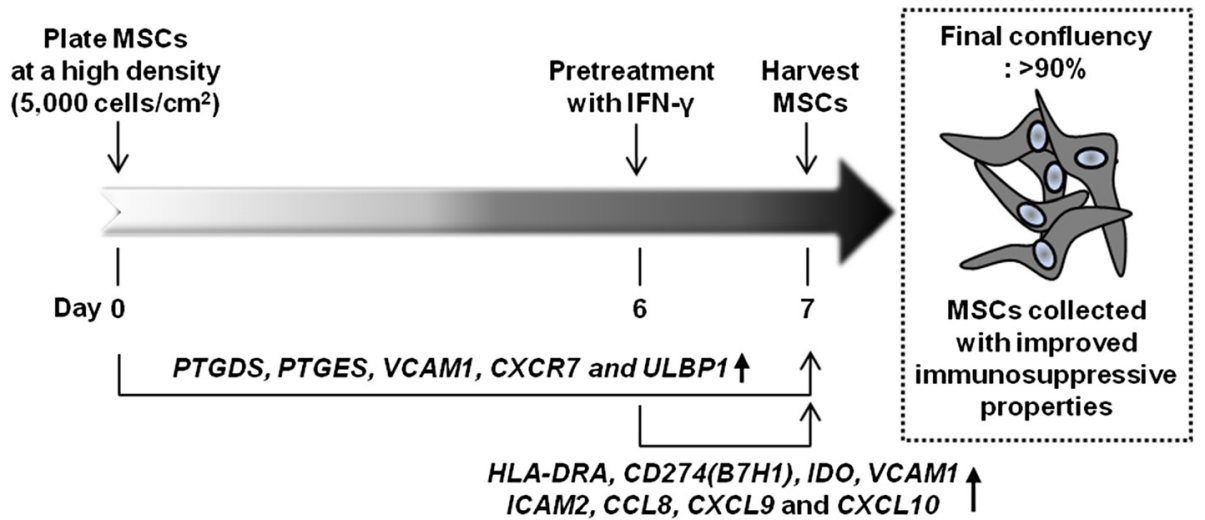

Fig. 1 Strategies to obtain human MSCs with improved immunosuppressive properties. CCL8 chemokine (C-C motif) ligand 8, CD274(B7H1) B7 homolog 1 (also known as programmed death-ligand 1), CXCL9 chemokine (C-X-C motif) ligand 9, CXCL10 chemokine (C-X-C motif) ligand 10, CXCR7 chemokine (C-X-C motif) receptor type 7, HLA-DRA major histocompatibility complex, class II, DR alpha chain, ICAM2 intercellular adhesion molecule 2, IDO indoleamine 2,3-dioxygenase, IFN-y interferon-gamma, MSC mesenchymal stem cell, PTGDS prostaglandin $D_{2}$ synthase, PTGES prostaglandin E synthase, ULBP1 natural-killer group 2 member D ligand 1, VCAM1 vascular cell adhesion protein 1 
in vitro [80]. Furthermore, various cytokines (e.g., interleukin (IL)-15 and -17) are involved in signaling pathways in which ULBP1 takes part [102, 103], although definite mechanisms and signals regulating their activation still need to be elucidated. These highly expressed genes may be involved in the immunosuppressive properties of MSCs, and further studies of their precise roles in MSC functions are required.

\section{Immunologically relevant effects of interferon-gamma}

Increasing numbers of pre-clinical studies and clinical trials of MSCs to treat immune-related disease have shown encouraging results; however, the mechanisms underlying the immunosuppressive effects of MSCs need to be further investigated in order to effectively adapt these cells for therapeutic applications. The ability of MSCs to modulate the activity of surrounding cells is not constitutive but rather activated by signals from a pro-inflammatory environment [104]. This process, termed priming or licensing, is extremely complex, and little is known about all of the factors and signaling pathways involved [105]. Several reports have shown the roles of IL-1, IFN- $\gamma$, and tumor necrosis factor-alpha (TNF- $\alpha$ ) in this process $[76,104,106]$. In particular, IFN- $\gamma$, the type II IFN, is a remarkable cytokine not only in innate and adaptive immunity to viral and bacterial infections but also in tumor control [107-111]. IFN- $\gamma$ was initially believed to be secreted only by CD4 Th1 lymphocytes, CD8 cytotoxic T lymphocytes, and NK cells; however, other types of cells, including B cells, NK T cells, and IL-12-stimulated APCs, can also produce IFN- $\gamma$ [107-109]. The main signaling pathway of IFN- $\gamma$ involves JAK/STAT, although it also mediates the phosphatidylinositol-3 kinase/Akt pathway, phosphorylation of phospholipase $\mathrm{C}-\gamma 2$, and the extracellular signal-regulated kinase cascade, demonstrating its complex and widespread biological functions [109, 110]. The cellular effects of IFN- $\gamma$ are notable because it can upregulate class I major histocompatibility complex (MHC), which is responsible for the host response to intracellular pathogens and the induction of cellmediated immunity, and class II MHC, which promotes peptide-specific activation of CD4 T cells [108]. The immunosuppressive properties of MSCs are activated by other immune-related factors through IFN- $\gamma$, by itself or in combination with one of three pro-inflammatory cytokines, namely, TNF- $\alpha$, IL- $1 \alpha$, and IL- $1 \beta$. This has been demonstrated in a number of studies using GVHD in vivo models; the recipients of IFN- $\gamma^{-1-} \mathrm{T}$ cells do not respond to MSCs, and MSCs obtained from IFNreceptor-1-deficient mice do not possess immunosuppressive functions $[2,112]$. In addition, after treatment with TNF- $\alpha$ and IFN- $\gamma$, MSCs are less effective at increasing pro-inflammatory cytokine production by activated peripheral blood derived-mononuclear cells and more efficient at inhibiting T-cell proliferation in an in vitro model [113]. TNF- $\alpha$ alone is sufficient to upregulate CXCR4 in MSCs in a time- and dose-dependent manner [114]. Lower expression of CXCR4 in MSCs leads to the failure of these cells to migrate into sites of inflammation and consequently reduces their immunosuppressive function [115]. Moreover, IL-1 $\beta$ released from monocytes enhances the secretion of transforming growth factor-beta by MSCs, which is involved in the inhibition of T-cell proliferation [104, 116]. In the presence of IFN- $\gamma$, either TNF- $\alpha$ or IL- $1 \alpha$ induces the expression of intercellular adhesion molecule 1 (ICAM1) and VCAM1, which are also essential for MSC-mediated immunosuppression [117].

\section{Upregulation of immunomodulation-related genes following preconditioning of mesenchymal stem cells with interferon-gamma}

We previously reported that activated $\mathrm{T}$ cells express higher levels of IFN- $\gamma$ than quiescent $\mathrm{T}$ cells and that IFN- $\gamma$ levels are significantly reduced when activated $\mathrm{T}$ cells are co-cultured with MSCs [118]. This is indicative of an IFN- $\gamma$ autocrine-paracrine loop. Therefore, priming of MSCs with IFN- $\gamma$, in addition to harvesting highly confluent cells, was expected to produce promising outcomes with regard to enhancing the immunomodulatory properties of MSCs. Indeed, 512 of 24,566 genes were upregulated in IFN- $\gamma$-preconditioned MSCs (Table 2). Specifically, immunomodulation-related genes, such as MHC, class II, DR alpha chain (HLA-DRA) , CD274 (B7 homolog 1 (B7H1)), indoleamine 2,3-dioxygenase (IDO), VCAM1, ICAM2, chemokine (C-C motif) ligand 8 (CCL8), chemokine (C-X-C motif) ligand 9 (CXCL9), and chemokine (C-X-C motif) ligand 10 (CXCL10), were dramatically upregulated by preconditioning MSCs with IFN- $\gamma$ (Fig. 1). The three identified chemokines (C-C or C-X-C motif)-namely, CCL8, CXCL9, and CXCL10-play important roles in the recruitment of leukocytes leading to various immune responses, whereas the other genes tend to be more directly involved in the immunomodulatory properties of MSCs [119-121]. Specifically, IDO, a well-known IFN- $\gamma$-induced gene, was highly upregulated in IFN- $\gamma$-preconditioned MSCs, and IDO suppresses antigen-driven proliferation of $\mathrm{T}$ cells [122-124]. IFN- $\gamma$ stimulated the expression of IDO in MSCs derived from sources other than BM, including human umbilical cord blood, adipose tissue, and Wharton's jelly (a gelatinous substance derived from the umbilical cord) [118]. The immunosuppressive activities of IDO are mediated via the degradation of tryptophan, an amino acid that is essential for T-cell proliferation [123-125]. Thus, IDO and a paucity of tryptophan have received particular attention in 
Table 2 Gene Ontology analysis based on immunomodulatory function-associated genes upregulated in IFN- - -treated MSC cultures

\begin{tabular}{|c|c|c|c|c|}
\hline Gene Ontology Category_Biological Process & Total number of genes & Number of upregulated genes & Enrichment & $P$ value \\
\hline GO:0006952_defense response & 9245 & 75 & 16.99 & $<0.001$ \\
\hline GO:0006954_inflammatory response & 2365 & 40 & 16.99 & $<0.001$ \\
\hline GO:0009611_response to wounding & 4854 & 49 & 16.99 & $<0.001$ \\
\hline GO:0019882_antigen processing and presentation & 1111 & 26 & 8.85 & $<0.001$ \\
\hline GO:0006955_immune response & 6130 & 39 & 8.85 & $<0.001$ \\
\hline GO:0005125_cytokine activity & 1242 & 22 & 5.85 & $<0.001$ \\
\hline GO:0050863_regulation of T-cell activation & 1122 & 17 & 3.74 & $<0.001$ \\
\hline GO:0042981_regulation of apoptotic process & 7118 & 44 & 3.58 & $<0.001$ \\
\hline GO:0002819_regulation of adaptive immune response & 536 & 10 & 2.73 & $<0.001$ \\
\hline GO:0045088_regulation of innate immune response & 852 & 9 & 2.33 & $<0.001$ \\
\hline
\end{tabular}

Microarray analysis was performed to evaluate the effect of IFN- $\gamma$ pre-treatment on MSCs. Upregulated genes in MSC cultures pre-treated with IFN- $\gamma$ were sorted on the basis of gene expression profiles (fold change $>2$ and $P$ value $<0.05$ ) and classified according to their related biological processes based on Gene Ontology terms by using DAVID Bioinformatics Resources 6.7

IFN- $\gamma$ interferon-gamma, MSC mesenchymal stem cell, DAVID Database for Annotation, Visualization and Integrated Discovery

many immune-related disorders. For example, patients with acute myeloid leukemia or adult T-cell leukemia/ lymphoma were reported to exhibit a higher ratio of kynurenine (a tryptophan metabolite) to tryptophan than healthy subjects [126]. Therefore, the enhanced immunosuppressive activities of MSCs seem to be highly associated with IFN- $\gamma$ priming and this is likely due in part to IDO induction. In addition, CD274 and HLA-DRA play a role during T-cell activation. HLA-DR encourages B7 subfamily members of immunoregulatory ligands to bind to $\mathrm{T}$-cell receptors, and the $\mathrm{B} 7 \mathrm{H} 1$ ligand (also known as CD274) inhibits T-cell responses [122, 127, 128]. In terms of in vivo adaptation, a few studies have revealed that BM transplantation of MSCs can control lethal GVHD, although this was not completely successful [129-131]. Furthermore, our unpublished study showed that mice injected with IFN- $\gamma$-pretreated MSCs had a higher rate of survival compared with those injected with untreated MSCs. Unfortunately MSCs are difficult to adapt as a first-line treatment for established GVHD because of the high cost and the lack of successful clinical data [132-134], and so MSCs harvested at a high density and preconditioned with IFN- $\gamma$ may provide a solution to improve the results of future clinical trials (Fig 1).

\section{Strategies to obtain mesenchymal stem cells with enhanced immunosuppressive properties}

In normal culture conditions, MSCs generally proliferate via cell division but rarely differentiate unless induced by particular differentiation conditions. Although low-density culture leads to faster proliferation, MSCs are initially plated at a lower density $\left(200\right.$ cells $\left./ \mathrm{cm}^{2}\right)[79,80,82,135]$ and it would take at least 2-3 weeks for MSCs to reach approximately $90 \%$ confluency, as is required. Although high-density culture leads to slower proliferation, MSCs are initially plated at a higher density $\left(5000\right.$ cells $\left./ \mathrm{cm}^{2}\right)$ and it takes an average of 7 days for cells to reach approximately $90 \%$ confluency. In these cells, the expression of genes related to their function is increased $[79,80,82,136,137]$. These cells continue to proliferate, albeit slowly, and become over-confluent when proliferation is further induced. As a result, cells are damaged and transformed. For this reason, after 7 days of culture at a high density $\left(5000\right.$ cells $\left./ \mathrm{cm}^{2}\right)$, cell confluency is around $90 \%$ and MSCs can be obtained in which the expression of some genes related to immunosuppressive properties is increased. In addition, we believe that IFN- $\gamma$ priming must be applied between 24 and 48 hours before MSCs are obtained for transplantation to use their improved immunosuppressive properties $[76,106,113,118]$. Therefore, we suggest that low-density culture and thereby faster proliferation are needed to secure a large amount of MSCs and that MSCs must be cultured at a high density for 1 week before transplantation to maximize their immunosuppressive properties (Fig. 1). Furthermore, MSCs must be cultured according to the 1-week protocol, in which IFN- $\gamma$ priming is applied between the fifth and sixth day and then cells are directly transplanted, to maximize the therapeutic effects of MSCs with improved immunosuppressive properties (Fig. 1).

\section{Conclusions}

Cell confluency is of critical importance to produce functionally qualified MSCs for clinical uses; however, it is unclear how cell confluency at the time of harvest, not seeding, alters the expression levels of genes that regulate a specific biological function, such as immunomodulation. Although a low cell confluency effectively improves the in vitro expansion capacity of MSCs, the levels of immunomodulation-related genes are augmented in highly confluent MSCs. By contrast, many biological function-related genes showed a varied expression profile, 
representing the heterogeneity of MSCs. Thus, we presumed that an additional ex vivo treatment is required to overcome MSC heterogeneity; indeed, priming of MSCs with IFN- $\gamma$ successfully improved their immunomodulatory functions. The expression profiles and functional analyses of specific genes presented herein suggest that MSCs with enhanced immunosuppressive properties can be produced by preconditioning MSCs that are almost confluent with IFN- $\gamma$. Therefore, these strategies are expected to provide useful guidelines for the collection of functionally qualified MSCs that can be readily adapted for further clinical uses, including therapies for immune-related disorders such as GVHD.

\section{Abbreviations}

APC: Antigen-presenting cell; B7H1: B7 homolog 1; BM: Bone marrow; CCL8: Chemokine (C-C motif) ligand 8; CXCL10: Chemokine (C-X-C motif) ligand 10; CXCL9: Chemokine (C-X-C motif) ligand 9; CXCR4: Chemokine (C-X-C motif) receptor type 4; CXCR7: Chemokine (C-X-C motif) receptor type 7; GVHD: Graft-versus-host disease; HLA-DRA: Major histocompatibility complex, class II, DR alpha chain; HSC: Hematopoietic stem cell; ICAM1: Intercellular adhesion molecule 1; IDO: Indoleamine 2,3-dioxygenase: IFN: Interferon; LL: Interleukin; ISCT: International Society for Cellular Therapy; MHC: Major histocompatibility complex; MSC: Mesenchymal stem cell; NK: Natural killer; NKG2D: Natural-killer group 2 member D; PG: Prostaglandin; PTGDS: Prostaglandin $D_{2}$ synthase; PTGES: Prostaglandin E synthase; TNF-a: Tumor necrosis factor-alpha; ULBP1: Natural-killer group 2 member D ligand 1; VCAM1: Vascular cell adhesion molecule 1; VLA4: Very late antigen 4.

\section{Competing interests}

The authors declare that they have no competing interests.

\section{Acknowledgments}

This research was supported by the Basic Science Research Program through the National Research Foundation of Korea funded by the Ministry of Education (2012R1A1A2007749, 2012R1A1A2041534, and 2014R1A1A2053629).

\section{Author details}

'Department of Pediatrics, Samsung Medical Center, Sungkyunkwan University School of Medicine, 50 Irwon-Dong, Gangnam-Gu, Seoul 135-710, Korea. ${ }^{2}$ Department of Health Sciences and Technology, SAIHST, Sungkyunkwan University, 50 Irwon-Dong, Gangnam-Gu, Seoul 135-710, Korea. ${ }^{3}$ Department of Medical Device Management and Research, SAIHST, Sungkyunkwan University, 50 Irwon-Dong, Gangnam-Gu, Seoul 135-710, Korea.

\section{Published online: 07 October 2015}

\section{References}

1. Salem HK, Thiemermann C. Mesenchymal stromal cells: current understanding and clinical status. Stem Cells. 2010;28:585-96.

2. Polchert D, Sobinsky J, Douglas G, Kidd M, Moadsiri A, Reina E, et al. IFN-gamma activation of mesenchymal stem cells for treatment and prevention of graft versus host disease. Eur J Immunol. 2008;38:1745-55.

3. Pittenger MF, Mackay AM, Beck SC, Jaiswal RK, Douglas R, Mosca JD, et al. Multilineage potential of adult human mesenchymal stem cells. Science. 1999;284:143-7.

4. Chen X, Armstrong MA, Li G. Mesenchymal stem cells in immunoregulation. Immunol Cell Biol. 2006:84:413-21.

5. Dazzi F, Krampera M. Mesenchymal stem cells and autoimmune diseases. Best Pract Res Clin Haematol. 2011:24:49-57.

6. Krampera M. Mesenchymal stromal cells: more than inhibitory cells. Leukemia. 2011:25:565-6.

7. Reyes M, Lund T, Lenvik T, Aguiar D, Koodie L, Verfaillie CM. Purification and ex vivo expansion of postnatal human marrow mesodermal progenitor cells. Blood. 2001;98:2615-25.
8. Phinney DG. Functional heterogeneity of mesenchymal stem cells: implications for cell therapy. J Cell Biochem. 2012;113:2806-12.

9. Phinney DG. Biochemical heterogeneity of mesenchymal stem cell populations: clues to their therapeutic efficacy. Cell Cycle. 2007:6:2884-9.

10. Sekiya I, Larson BL, Smith JR, Pochampally R, Cui JG, Prockop DJ. Expansion of human adult stem cells from bone marrow stroma: conditions that maximize the yields of early progenitors and evaluate their quality. Stem Cells. 2002:20:530-41.

11. Sotiropoulou PA, Perez SA, Salagianni M, Baxevanis CN, Papamichail M. Characterization of the optimal culture conditions for clinical scale production of human mesenchymal stem cells. Stem Cells. 2006;24:462-71.

12. Vogel W, Grünebach F, Messam CA, Kanz L, Brugger W, Bühring HJ. Heterogeneity among human bone marrow-derived mesenchymal stem cells and neural progenitor cells. Haematologica. 2003;88:126-33.

13. Friedenstein AJ, Petrakova KV, Kurolesova Al, Frolova GP. Heterotopic of bone marrow. Analysis of precursor cells for osteogenic and hematopoietic tissues. Transplantation. 1968:6:230-47.

14. Friedenstein AJ, Chailakhyan RK, Gerasimov UV. Bone marrow osteogenic stem cells: in vitro cultivation and transplantation in diffusion chambers. Cell Tissue Kinet. 1987;20:263-72.

15. Dominici M, Le Blanc K, Mueller I, Slaper-Cortenbach I, Marini F, Krause D, et al. Minimal criteria for defining multipotent mesenchymal stromal cells, The International Society for Cellular Therapy position statement. Cytotherapy. 2006:8:315-7.

16. Phinney DG, Kopen G, Isaacson RL, Prockop DJ. Plastic adherent stromal cells from the bone marrow of commonly used strains of inbred mice: variations in yield, growth, and differentiation. J Cell Biochem. 1999;72:570-85.

17. Phinney DG, Kopen G, Righter W, Webster S, Tremain N, Prockop DJ. Donor variation in the growth properties and osteogenic potential of human marrow stromal cells. J Cell Biochem. 1999;75:424-36.

18. Samuelsson $H$, Ringdén $O$, Lönnies $H$, Le Blanc K. Optimizing in vitro conditions for immunomodulation and expansion of mesenchymal stromal cells. Cytotherapy. 2009;11:129-36

19. Siddappa R, Licht $R$, van Blitterswijk C, de Boer J. Donor variation and loss of multipotency during in vitro expansion of human mesenchymal stem cells for bone tissue engineering. J Orthop Res. 2007;25:1029-41.

20. Wagner W, Ho AD. Mesenchymal stem cell preparations-comparing apples and oranges. Stem Cell Rev. 2007:3:239-48.

21. Owen M. Marrow stromal stem cells. J Cell Sci. 1988;10:63-76.

22. Caplan Al. Mesenchymal stem cells. J Orthop Res. 1991;9:641-50.

23. Young RG, Butler DL, Weber W, Caplan Al, Gordon SL, Fink DJ. Use of mesenchymal stem cells in a collagen matrix for Achilles tendon repair. J Orthop Res. 1998;16:406-13.

24. Wakitani S, Saito T, Caplan Al. Myogenic cells derived from rat bone marrow mesenchymal stem cells exposed to 5-azacytidine. Muscle Nerve. 1995;18:1417-26.

25. Dennis JE, Caplan Al. Differentiation potential of conditionally immortalized mesenchymal progenitor cells from adult marrow of a $\mathrm{H}-2 \mathrm{~Kb}$-ts $\mathrm{A} 58$ transgenic mouse. J Cell Physiol. 1996;167:523-38.

26. Dexter TM, Testa NG. Differentiation and proliferation of hemopoietic cells in culture. Methods Cell Biol. 1976;14:387-405.

27. Friedrich C, Zausch E, Sugrue SP, Gutierrez-Ramos JC. Hematopoietic supportive functions of mouse bone marrow and fetal liver microenvironment: dissection of granulocyte, B-lymphocyte, and hematopoietic progenitor support at the stroma cell clone level. Blood. 1996;87:4596-606.

28. Krampera M, Glennie S, Dyson J, Scott D, Laylor R, Simpson E, et al. Bone marrow mesenchymal stem cells inhibit the response of naive and memory antigen-specific T cells to their cognate peptide. Blood. 2003;101:3722-9.

29. Tse WT, Pendleton JD, Beyer WM, Egalka MC, Guinan EC. Suppression of allogeneic T-cell proliferation by human marrow stromal cells: implications in transplantation. Transplantation. 2003;75:389-97.

30. Zappia E, Casazza S, Pedemonte E, Benvenuto F, Bonanni I, Gerdoni E, et al. Mesenchymal stem cells ameliorate experimental autoimmune encephalomyelitis inducing T-cell anergy. Blood. 2005;106:1755-61.

31. Ortiz LA, Gambelli F, McBride C, Gaupp D, Baddoo M, Kaminski N, et al. Mesenchymal stem cell engraftment in lung is enhanced in response to bleomycin exposure and ameliorates its fibrotic effects. Proc Natl Acad Sci U S A. 2003;100:8407-11.

32. Ciccocioppo R, Bernardo ME, Sgarella A, Maccario R, Avanzini MA, Ubezio C, et al. Autologous bone marrow-derived mesenchymal stromal cells in the treatment of fistulising Crohn's disease. Gut. 2011;60:788-98. 
33. Tang $Y$, Chen $Y$, Wang $X$, Song G, Li Y, Shi L. Combinatorial intervention with mesenchymal stem cells and granulocyte colony-stimulating factor in a rat model of ulcerative colitis. Dig Dis Sci. 2015;60:1948-57.

34. Prasad VK, Lucas KG, Kleiner Gl, Talano JA, Jacobsohn D, Broadwater G, et al. Efficacy and safety of ex vivo cultured adult human mesenchymal stem cells (Prochymal ${ }^{\mathrm{TM}}$ ) in pediatric patients with severe refractory acute graftversus-host disease in a compassionate use study. Biol Blood Marrow Transplant. 2011;17:534-41.

35. Muroi K, Miyamura K, Ohashi K, Murata M, Eto T, Kobayashi N, et al. Unrelated allogeneic bone marrow-derived mesenchymal stem cells for steroid-refractory acute graft-versus-host disease: a phase I/II study. Int J Hematol. 2013:98:206-13.

36. Peng Y, Chen X, Liu Q, Zhang X, Huang K, Liu L, et al. Mesenchymal stromal cells infusions improve refractory chronic graft versus host disease through an increase of CD5+ regulatory B cells producing interleukin 10. Leukemia. 2015;29:636-46.

37. Yoshimatsu G, Sakata N, Tsuchiya H, Minowa T, Takemura T, Morita H, et al. The co-transplantation of bone marrow derived mesenchymal stem cells reduced inflammation in intramuscular islet transplantation. PLoS One. 2015;10, e0117561.

38. Cortinovis M, Casiraghi F, Remuzzi G, Perico N. Mesenchymal stromal cells to control donor-specific memory T cells in solid organ transplantation. Curr Opin Organ Transplant. 2015;20:79-85.

39. Dominici M, Paolucci $P$, Conte P, Horwitz EM. Heterogeneity of multipotent mesenchymal stromal cells: from stromal cells to stem cells and vice versa. Transplantation. 2009;87(9 Suppl):S36-42.

40. Le Blanc K, Frassoni F, Ball L, Locatelli F, Roelofs H, Lewis I, et al. Mesenchymal stem cells for treatment of steroid-resistant, severe, acute graft-versus-host disease: a phase II study. Lancet. 2008;371:1579-86.

41. Meirelles Lda S, Nardi NB. Methodology, biology and clinical applications of mesenchymal stem cells. Front Biosci (Landmark Ed). 2009;14:4281-98.

42. Pevsner-Fischer M, Levin S, Zipori D. The origins of mesenchymal stromal cell heterogeneity. Stem Cell Rev. 2011;7:560-8.

43. Ho AD, Wagner W, Franke W. Heterogeneity of mesenchymal stromal cell preparations. Cytotherapy. 2008;10:320-30.

44. Hwang JH, Shim SS, Seok OS, Lee HY, Woo SK, Kim BH, et al. Comparison of cytokine expression in mesenchymal stem cells from human placenta, cord blood, and bone marrow. J Korean Med Sci. 2009;24:547-54.

45. English K, French A, Wood KJ. Mesenchymal stromal cells: facilitators of successful transplantation? Cell Stem Cell. 2010;7:431-42.

46. Webb TL, Quimby JM, Dow SW. In vitro comparison of feline bone marrow-derived and adipose tissue-derived mesenchymal stem cells. J Feline Med Surg. 2012;14:165-8.

47. da Silva Meirelles L, Caplan Al, Nardi NB. In search of the in vivo identity of mesenchymal stem cells. Stem Cells. 2008:26:2287-99.

48. Meirelles Lda S, Fontes AM, Covas DT, Caplan Al. Mechanisms involved in the therapeutic properties of mesenchymal stem cells. Cytokine Growth Factor Rev. 2009;20:419-27.

49. Boiret N, Rapatel C, Veyrat-Masson R, Guillouard L, Guérin JJ, Pigeon P, et al. Characterization of nonexpanded mesenchymal progenitor cells from normal adult human bone marrow. Exp Hematol. 2005:33:219-25.

50. Aslan H, Zilberman Y, Kandel L, Liebergall M, Oskouian RJ, Gazit D, et al. Osteogenic differentiation of noncultured immunoisolated bone marrow-derived CD105+ cells. Stem Cells. 2006;24:1728-37.

51. Gronthos S, Zannettino AC, Hay SJ, Shi S, Graves SE, Kortesidis A, et al. Molecular and cellular characterisation of highly purified stromal stem cells derived from human bone marrow. J Cell Sci. 2003:116(Pt 9):1827-35.

52. Quirici N, Soligo D, Bossolasco P, Servida F, Lumini C, Deliliers GL. Isolation of bone marrow mesenchymal stem cells by anti-nerve growth factor receptor antibodies. Exp Hematol. 2002;30:783-91.

53. Battula VL, Treml S, Bareiss PM, Gieseke F, Roelofs H, de Zwart P, et al. Isolation of functionally distinct mesenchymal stem cell subsets using antibodies against CD56, CD271, and mesenchymal stem cell antigen-1. Haematologica. 2009;94:173-84.

54. Simmons PJ, Torok-Storb B. Identification of stromal cell precursors in human bone marrow by a novel monoclonal antibody, STRO-1. Blood. 1991:78:55-62.

55. Gang EJ, Bosnakovski D, Figueiredo CA, Visser JW, Perlingeiro RC. SSEA-4 identifies mesenchymal stem cells from bone marrow. Blood. 2007;109:1743-51.

56. Mabuchi Y, Houlihan DD, Akazawa C, Okano H, Matsuzaki Y. Prospective isolation of murine and human bone marrow mesenchymal stem cells based on surface markers. Stem Cells Int. 2013;2013:507301.
57. Gottipamula S, Muttigi MS, Kolkundkar U, Seetharam RN. Serum-free media for the production of human mesenchymal stromal cells: a review. Cell Prolif. 2013;46:608-27.

58. Al-Saqi SH, Saliem M, Asikainen S, Quezada HC, Ekblad A, Hovatta O, et al. Defined serum-free media for in vitro expansion of adipose-derived mesenchymal stem cells. Cytotherapy. 2014;16:915-26.

59. Jung S, Panchalingam KM, Rosenberg L, Behie LA. Ex vivo expansion of human mesenchymal stem cells in defined serum-free media. Stem Cells Int. 2012;2012:123030.

60. Chase LG, Lakshmipathy U, Solchaga LA, Rao MS, Vemuri MC. A novel serum-free medium for the expansion of human mesenchymal stem cells. Stem Cell Res Ther. 2010;1:8.

61. Wang S, Zhou Y, Andreyev O, Hoyt Jr RF, Singh A, Hunt T, et al. Overexpression of FABP3 inhibits human bone marrow derived mesenchymal stem cell proliferation but enhances their survival in hypoxia. Exp Cell Res. 2014;323:56-65.

62. Peterson KM, Aly A, Lerman A, Lerman LO, Rodriguez-Porcel M. Improved survival of mesenchymal stromal cell after hypoxia preconditioning: role of oxidative stress. Life Sci. 2011;88:65-73.

63. Dos Santos F, Andrade PZ, Boura JS, Abecasis MM, da Silva CL, Cabral JM. Ex vivo expansion of human mesenchymal stem cells: a more effective cell proliferation kinetics and metabolism under hypoxia. J Cell Physiol. 2010;223:27-35

64. Lee HJ, Ryu JM, Jung YH, Oh SY, Lee SJ, Han HJ. Novel pathway for hypoxiainduced proliferation and migration in human mesenchymal stem cells: involvement of HIF-1a, FASN, and mTORC1. Stem Cells. 2015;33:2182-95.

65. Drela K, Sarnowska A, Siedlecka P, Szablowska-Gadomska I, Wielgos M, Jurga $M$, et al. Low oxygen atmosphere facilitates proliferation and maintains undifferentiated state of umbilical cord mesenchymal stem cells in an hypoxia inducible factor-dependent manner. Cytotherapy. 2014;16:881-92.

66. Shang J, Liu H, Li J, Zhou Y. Roles of hypoxia during the chondrogenic differentiation of mesenchymal stem cells. Curr Stem Cell Res Ther. 2014;9:141-7.

67. Valorani MG, Montelatici E, Germani A, Biddle A, D'Alessandro D, Strollo R, et al. Pre-culturing human adipose tissue mesenchymal stem cells under hypoxia increases their adipogenic and osteogenic differentiation potentials. Cell Prolif. 2012;45:225-38.

68. Crisostomo PR, Wang Y, Markel TA, Wang M, Lahm T, Meldrum DR. Human mesenchymal stem cells stimulated by TNF-alpha, LPS, or hypoxia produce growth factors by an NF kappa B- but not JNK-dependent mechanism. Am J Physiol Cell Physiol. 2008;294:C675-82.

69. Du L, Yu Y, Ma H, Lu X, Ma L, Jin Y, et al. Hypoxia enhances protective effect of placental-derived mesenchymal stem cells on damaged intestinal epithelial cells by promoting secretion of insulin-like growth factor-1. Int J Mol Sci. 2014:15:1983-2002

70. Li Z, Wei H, Deng L, Cong X, Chen X. Expression and secretion of interleukin-1 $\beta$, tumour necrosis factor- $a$ and interleukin-10 by hypoxia- and serum-deprivation-stimulated mesenchymal stem cells. FEBS J. 2010;277:3688-98

71. Vertelov G, Kharazi L, Muralidhar MG, Sanati G, Tankovich T, Kharazi A. High targeted migration of human mesenchymal stem cells grown in hypoxia is associated with enhanced activation of RhoA. Stem Cell Res Ther. 2013;4:5.

72. Saller MM, Prall WC, Docheva D, Schönitzer V, Popov T, Anz D, et al. Increased stemness and migration of human mesenchymal stem cells in hypoxia is associated with altered integrin expression. Biochem Biophys Res Commun. 2012:423:379-85.

73. Paul S, Calmels B, Acres RB. Improvement of adoptive cellular immunotherapy of human cancer using ex-vivo gene transfer. Curr Gene Ther. 2002;2:91-100.

74. Down JD, White-Scharf ME. Reprogramming immune responses: enabling cellular therapies and regenerative medicine. Stem Cells. 2003:21:21-32.

75. Taddio A, Tommasini A, Valencic E, Biagi E, Decorti G, De ludicibus S, et al. Failure of interferon- $\gamma$ pre-treated mesenchymal stem cell treatment in a patient with Crohn's disease. World J Gastroenterol. 2015;21:4379-84.

76. Krampera $M$, Cosmi L, Angeli $R$, Pasini A, Liotta F, Andreini $A$, et al. Role for interferon-gamma in the immunomodulatory activity of human bone marrow mesenchymal stem cells. Stem Cells. 2006;24:386-98.

77. Lian Q, Lye E, Suan Yeo K, Khia Way Tan E, Salto-Tellez M, Liu TM, et al. Derivation of clinically compliant MSCs from CD105+, CD24- differentiated human ESCs. Stem Cells. 2007;25:425-36.

78. Kulterer B, Friedl G, Jandrositz A, Sanchez-Cabo F, Prokesch A, Paar C, et al. Gene expression profiling of human mesenchymal stem cells derived from bone marrow during expansion and osteoblast differentiation. BMC Genomics. 2007;8:70 
79. Kim DS, Lee MW, Yoo KH, Lee TH, Kim HJ, Jang IK, et al. Gene expression profiles of human adipose tissue-derived mesenchymal stem cells are modified by cell culture density. PLoS One. 2014;9, e83363.

80. Lee MW, Kim DS, Ryu S, Jang IK, Kim HJ, Yang JM, et al. Effect of ex vivo culture conditions on immunosuppression by human mesenchymal stem cells. Biomed Res Int. 2013:2013:154919.

81. Sawada R, Ito T, Tsuchiya T. Changes in expression of genes related to cell proliferation in human mesenchymal stem cells during in vitro culture in comparison with cancer cells. J Artif Organs. 2006;9:179-84.

82. Lee MW, Kim DS, Yoo KH, Kim HR, Jang IK, Lee JH, et al. Human bone marrow-derived mesenchymal stem cell gene expression patterns vary with culture conditions. Blood Res. 2013;48:107-14.

83. Hata AN, Breyer RM. Pharmacology and signaling of prostaglandin receptors: multiple roles in inflammation and immune modulation. Pharmacol Ther. 2004;103:147-66.

84. Harris SG, Padilla J, Koumas L, Ray D, Phipps RP. Prostaglandins as modulators of immunity. Trends Immunol. 2002;23:144-50.

85. Korotkova M, Daha NA, Seddighzadeh M, Ding B, Catrina Al, Lindblad S, et al. Variants of gene for microsomal prostaglandin E2 synthase show association with disease and severe inflammation in rheumatoid arthritis. Eur J Hum Genet. 2011;19:908-14.

86. Spaeth E, Klopp A, Dembinski J, Andreeff M, Marini F. Inflammation and tumor microenvironments: defining the migratory itinerary of mesenchymal stem cells. Gene Ther. 2008;15:730-8.

87. Dai $X$, Tan $Y$, Cai $S$, Xiong X, Wang $L$, Ye Q, et al. The role of CXCR7 on the adhesion, proliferation and angiogenesis of endothelial progenitor cells. J Cell Mol Med. 2011;15:1299-309.

88. Kumar R, Tripathi V, Ahmad M, Nath N, Mir RA, Chauhan SS, et al. CXCR7 mediated Gia independent activation of ERK and Akt promotes cell survival and chemotaxis in T cells. Cell Immunol. 2012;272:230-41.

89. Lee E, Han J, Kim K, Choi H, Cho EG, Lee TR. CXCR7 mediates SDF1-induced melanocyte migration. Pigment Cell Melanoma Res. 2013;26:58-66.

90. Tarnowski M, Liu R, Wysoczynski M, Ratajczak J, Kucia M, Ratajczak MZ. CXCR7: a new SDF-1-binding receptor in contrast to normal CD34(+) progenitors is functional and is expressed at higher level in human malignant hematopoietic cells. Eur J Haematol. 2010;85:472-83.

91. Li Q, Zhang A, Tao C, Li X, Jin P. The role of SDF-1-CXCR4/CXCR7 axis in biological behaviors of adipose tissue-derived mesenchymal stem cells in vitro. Biochem Biophys Res Commun. 2013;441:675-80.

92. Liu H, Liu S, Li Y, Wang X, Xue W, Ge G, et al. The role of SDF-1-CXCR4/ CXCR7 axis in the therapeutic effects of hypoxia-preconditioned mesenchymal stem cells for renal ischemia/reperfusion injury. PLoS One. 2012;7, e34608.

93. Segers VF, Van Riet I, Andries LJ, Lemmens K, Demolder MJ, De Becker AJ, et al. Mesenchymal stem cell adhesion to cardiac microvascular endothelium: activators and mechanisms. Am J Physiol Heart Circ Physiol. 2006:290:H1370-7.

94. Rüster B, Göttig S, Ludwig RJ, Bistrian R, Müller S, Seifried E, et al. Mesenchymal stem cells display coordinated rolling and adhesion behavior on endothelial cells. Blood. 2006;108:3938-44.

95. Ou R, Zhang M, Huang L, Flavell RA, Koni PA, Moskophidis D. Regulation of immune response and inflammatory reactions against viral infection by VCAM-1. J Virol. 2008;82:2952-65.

96. Nishihira S, Okubo N, Takahashi N, Ishisaki A, Sugiyama Y, Chosa N. High-cell density-induced VCAM1 expression inhibits the migratory ability of mesenchymal stem cells. Cell Biol Int. 2011;35:475-81.

97. Wang CM, Guo Z, Xie YJ, Hao YY, Sun JM, Gu J, et al. Co-treating mesenchymal stem cells with IL-1 $\beta$ and TNF- $\alpha$ increases VCAM-1 expression and improves post-ischemic myocardial function. Mol Med Rep. 2014;10:792-8.

98. González S, Groh V, Spies T. Immunobiology of human NKG2D and its ligands. Curr Top Microbiol Immunol. 2006;298:121-38.

99. Textor S, Fiegler N, Arnold A, Porgador A, Hofmann TG, Cerwenka A. Human NK cells are alerted to induction of p53 in cancer cells by upregulation of the NKG2D ligands ULBP1 and ULBP2. Cancer Res. 2011;71:5998-6009.

100. Dai Z, Turtle CJ, Booth GC, Riddell SR, Gooley TA, Stevens AM, et al. Normally occurring NKG2D + CD4+ T cells are immunosuppressive and inversely correlated with disease activity in juvenile-onset lupus. J Exp Med. 2009;206:793-805

101. Hanaoka N, Nakakuma H, Horikawa K, Nagakura S, Tsuzuki Y, Shimanuki M, et al. NKG2D-mediated immunity underlying paroxysmal nocturnal haemoglobinuria and related bone marrow failure syndromes. $\mathrm{Br} \mathrm{J}$ Haematol. 2009;146:538-45

102. Dejaco C, Duftner C, Al-Massad J, Wagner AD, Park JK, Fessler J, et al. NKG2D stimulated T-cell autoreactivity in giant cell arteritis and polymyalgia rheumatica. Ann Rheum Dis. 2013;72:1852-9.

103. Paidipally P, Periasamy S, Barnes PF, Dhiman $R$, Indramohan $M$, Griffith DE, et al. NKG2D-dependent IL-17 production by human $T$ cells in response to an intracellular pathogen. J Immunol. 2009;183:1940-5.

104. Groh ME, Maitra B, Szekely E, Koç ON. Human mesenchymal stem cells require monocyte-mediated activation to suppress alloreactive T cells. Exp Hematol. 2005;33:928-34.

105. Krampera M. Mesenchymal stromal cell 'licensing': a multistep process. Leukemia. 2011;25:1408-14.

106. Ryan JM, Barry F, Murphy JM, Mahon BP. Interferon-gamma does not break but promotes the immunosuppressive capacity of adult human mesenchymal stem cells. Clin Exp Immunol. 2007;149:353-63.

107. Dalton DK, Pitts-Meek S, Keshav S, Figari IS, Bradley A, Stewart TA. Multiple defects of immune cell function in mice with disrupted interferon-gamma genes. Science. 1993;259:1739-42.

108. Schoenborn JR, Wilson CB. Regulation of interferon-gamma during innate and adaptive immune responses. Adv Immunol. 2007;96:41-101.

109. Schroder K, Hertzog PJ, Ravasi T, Hume DA. Interferon-gamma: an overview of signals, mechanisms and functions. J Leukoc Biol. 2004;75:163-89.

110. Shtrichman R, Samuel CE. The role of gamma interferon in antimicrobial immunity. Curr Opin Microbiol. 2001:4:251-9.

111. Chesler DA, Reiss CS. The role of IFN-gamma in immune responses to viral infections of the central nervous system. Cytokine Growth Factor Rev. 2002;13:441-54

112. Ren G, Zhang L, Zhao X, Xu G, Zhang Y, Roberts Al, et al. Mesenchymal stem cell-mediated immunosuppression occurs via concerted action of chemokines and nitric oxide. Cell Stem Cell. 2008;2:141-50.

113. Cuerquis J, Romieu-Mourez R, François M, Routy JP, Young YK, Zhao J, et al. Human mesenchymal stromal cells transiently increase cytokine production by activated T cells before suppressing T-cell proliferation: effect of interferon- $\gamma$ and tumor necrosis factor-a stimulation. Cytotherapy. 2014;16:191-202.

114. Ziaei R, Ayatollahi M, Yaghobi R, Sahraeian Z, Zarghami N. Involvement of TNF-a in differential gene expression pattern of CXCR4 on human marrowderived mesenchymal stem cells. Mol Biol Rep. 2014;41:1059-66.

115. Xu J, Wang D, Liu D, Fan Z, Zhang H, Liu O, et al. Allogeneic mesenchymal stem cell treatment alleviates experimental and clinical Sjögren syndrome. Blood. 2012;120:3142-51.

116. Cutler AJ, Limbani V, Girdlestone J, Navarrete CV. Umbilical cord-derived mesenchymal stromal cells modulate monocyte function to suppress $T$ cell proliferation. J Immunol. 2010;185:6617-23.

117. Ren G, Zhao X, Zhang L, Zhang J, L'Huillier A, Ling W, et al. Inflammatory cytokine-induced intercellular adhesion molecule-1 and vascular cell adhesion molecule-1 in mesenchymal stem cells are critical for immunosuppression. J Immunol. 2010;184:2321-8.

118. Yoo KH, Jang IK, Lee MW, Kim HE, Yang MS, Eom Y, et al. Immunomodulatory properties of mesenchymal stem cells derived from adult human tissues. Cell Immunol. 2009;259:150-6.

119. Stec M, Baran J, Baj-Krzyworzeka M, Weglarczyk K, Gozdzik J, Siedlar M, et al. Chemokine receptors and chemokine production by CD34+ stem cell-derived monocytes in response to cancer cells. Anticancer Res. 2012;32:4749-53.

120. Yamamoto M, Ota A, Hori T, Imai S, Sohma H, Suzuki N, et al. Early expression of plasma CCL8 closely correlates with survival rate of acute graft-vs-host disease in mice. Exp Hematol. 2011;39:1101-12.

121. Müller M, Carter S, Hofer MJ, Campbell IL. The chemokine receptor CXCR3 and its ligands CXCL9, CXCL10 and CXCL11 in neuroimmunity-a tale of conflict and conundrum. Neuropathol Appl Neurobiol. 2010;36:368-87.

122. Munn DH, Sharma MD, Mellor AL. Ligation of B7-1/B7-2 by human CD4+ T cells triggers indoleamine 2,3-dioxygenase activity in dendritic cells. J Immunol. 2004;172:4100-10.

123. Spaggiari GM, Capobianco A, Abdelrazik H, Becchetti F, Mingari MC, Moretta L. Mesenchymal stem cells inhibit natural killer-cell proliferation, cytotoxicity, and cytokine production: role of indoleamine 2,3-dioxygenase and prostaglandin E2. Blood. 2008;111:1327-33.

124. Fallarino F, Grohmann U. Using an ancient tool for igniting and propagating immune tolerance: IDO as an inducer and amplifier of regulatory $T$ cell functions. Curr Med Chem. 2011;18:2215-21. 
125. Tan PH, Bharath AK. Manipulation of indoleamine 2,3 dioxygenase; a novel therapeutic target for treatment of diseases. Expert Opin Ther Targets. 2009;13:987-1012.

126. Kurz K, Gluhcheva Y, Zvetkova E, Konwalinka G, Fuchs D. Interferon-gammamediated pathways are induced in human CD34(+) haematopoietic stem cells. Immunobiology. 2010;215:452-7.

127. Dustin ML. T-cell activation through immunological synapses and kinapses Immunol Rev. 2008;221:77-89.

128. Jang IK, Yoon HH, Yang MS, Lee JE, Lee DH, Lee MW, et al. B7-H1 inhibits T cell proliferation through MHC class II in human mesenchymal stem cells. Transplant Proc. 2014;46:1638-41.

129. Yañez R, Lamana ML, García-Castro J, Colmenero I, Ramírez M, Bueren JA. Adipose tissue-derived mesenchymal stem cells have in vivo immunosuppressive properties applicable for the control of the graftversus-host disease. Stem Cells. 2006;24:2582-91.

130. Sudres M, Norol F, Trenado A, Grégoire S, Charlotte F, Levacher B, et al. Bone marrow mesenchymal stem cells suppress lymphocyte proliferation in vitro but fail to prevent graft-versus-host disease in mice. J Immunol. 2006;176:7761-7.

131. Hoogduijn MJ, Popp F, Verbeek R, Masoodi M, Nicolaou A, Baan C, et al. The immunomodulatory properties of mesenchymal stem cells and their use for immunotherapy. Int Immunopharmacol. 2010;10:1496-500.

132. Giordano A, Galderisi U, Marino IR. From the laboratory bench to the patient's bedside: an update on clinical trials with mesenchymal stem cells. J Cell Physiol. 2007;211:27-35

133. Momin EN, Vela G, Zaidi HA, Quiñones-Hinojosa A. The oncogenic potential of mesenchymal stem cells in the treatment of cancer: directions for future research. Curr Immunol Rev. 2010;6:137-48.

134. Prockop DJ, Olson SD. Clinical trials with adult stem/progenitor cells for tissue repair: let's not overlook some essential precautions. Blood. 2007;109:3147-51.

135. Yoon DS, Kim YH, Jung HS, Paik S, Lee JW. Importance of Sox2 in maintenance of cell proliferation and multipotency of mesenchymal stem cells in low-density culture. Cell Prolif. 2011;44:428-40.

136. Ryu H, Oh JE, Rhee KJ, Baik SK, Kim J, Kang SJ, et al. Adipose tissue-derived mesenchymal stem cells cultured at high density express IFN- $\beta$ and suppress the growth of MCF-7 human breast cancer cells. Cancer Lett. 2014;352:220-7.

137. Romieu-Mourez R, François M, Boivin MN, Stagg J, Galipeau J. Regulation of MHC class II expression and antigen processing in murine and human mesenchymal stromal cells by IFN-gamma, TGF-beta, and cell density. J Immunol. 2007;179:1549-58 